\title{
Incorporating Motor Aspects in a Competence- based Syllabus for Second-Grade English Class in SD Muhammadiyah Jagalan
}

\author{
Cisya Dewantara Nugraha, S.S., M.A.,' Dian Ayu Septiani Wiwitan² \\ Lecturer, Diploma of English, SV-UGM \\ cisya.d.nugraha@ugm.ac.id \\ Students, Diploma of English, SV-UGM \\ septianiwiwitan@gmail.com
}

\begin{abstract}
This paper aims to describe the development and implementation of competence-based syllabus of English in the second-grade class of SD Muhammadiyah Jagalan. The research data were collected through direct observation and interviews with teachers and headmaster in SD Muhammadiyah Jagalan. Quotes from several books and references were used to support the analysis. The result showed that there are five stages to incorporate motor aspect in developing a competence-based syllabus, namely implementing the principles, formulating the set of procedures, implementing the development process, and formatting and modelling the developed syllabus based on KBK. The developed syllabus was then implemented in the class. The result showed that the developed syllabus brought positive impact for the students' learning process in class. The impact includes the increasing attention of students to the material explained by the teacher in the class, the building up of student's self-confidence, and the growing interest of students to participate in the class when the teacher gives assignments.
\end{abstract}

Keywords: English, Motor aspect, Syllabus development, SD Muhammadiyah Jagalan

\section{Intisari}

Makalah ini memaparkan tentang pengembangan dan penerapan silabus berbasis kompetensi pada mata pelajaran bahasa Inggris di kelas dua SD Muhammadiyah Jagalan. Data penelitian dikumpulkan melalui pengamatan langsung dan beberapa wawancara dengan guru-guru dan kepala sekolah di SD Islam Muhammadiyah Jagalan. Kutipan dari beberapa buku dan referensi digunakan untuk mendukung analisis. Hasilnya menunjukkan bahwa ada lima tahapan yang dilalui dalam memasukkan aspek motorik dalam pengembangan silabus berbasis kompetensi, meliputi inkorporasi prinsip pengembangan silabus, implementasi prosedur, proses pengembangan silabus, penyusunan format dan pemodelan silabus. Silabus yang telah dikembangkan kemudian diimplementasikan dalam pengajaran di kelas. Hasilnya menunjukkan bahwa silabus yang telah dikembangkan membawa dampak positif bagi pembelajaran siswa. Dampak positif tersebut meliputi meningkatnya perhatian siswa pada penjelasan guru tentang materi ajar di kelas, meningkatnya kepercayaan diri siswa dan meningkatnya minat siswa untuk berpartisipasi di kelas saat guru memberikan tugas.

Kata Kunci: Bahasa Inggris, Pengembangan Syllabus,Sekolah Dasar Islam Muhammadiyah Jagalan, penyusunan silabus, implementasi silabus 


\section{Introduction}

Learning process is a system that is required in carrying out the task of education. It can start from a better teaching activities program, specification of teaching program, and arranging teaching plans. Rooijakers (1991:114) stated that "learning process is learning activities that is related to educators, learners, and the interaction process between educator and learner and resource in a study area in the education program feasibility". The meaning of state is that in arranging education program resource is very important in deciding the learning activities. In the learning activities program, there are four sets of learning program namely; Yearly Program, Semester Program, Rencana Pelaksanaan Pembelajaran (RPP) or Lesson Plan, and syllabus (Muhammad Falah, 2014).

In the field of education, syllabus is an obligatory tool for teacher to teach their subjects at school. There are several purposes for teacher to make syllabus, which are: (1) as a reference to develop students' performative skills in class, (2) lesson plans, (3) an organization activity of the subjects learned, and to develop of the assessment system in the class. According to Peraturan Pemerintah Republik Indonesia number 19, 2005 "The planning of learning process including; syllabus and lesson plans, learning material, teaching methods, learning resources, and the result of study assessment." (Qtd. in Belajar dan Pembelajaran 4). From the quotation above, syllabus is one of learning process for students in the class which contains learning activities, class management, and the assessment of learning results organized by the teacher.

The definition of syllabus is "an outline of subject, a summary, succinct, or main contents in subject materials." (Salim, 199:98 qtd. in Panduan Umum Pengembangan Silabus 16). Another definition mentioned that, "Syllabus is lesson plan in some subjects or groups of subject includes; competence standard, basic competence, learning material, learning activities, the achievement of indicators competence for assessment, time allocation, and study resources." (Trianto, 2011). From those definitions, it can be inferred that syllabus is an organized set of plans that manage learning activities, classroom management, and result of study in some subjects.

The syllabus explained above is related to the writer's two-month internship program in the Islamic Elementary School Muhammadiyah 
Jagalan. During the internship program, the writer worked as an English teacher who had duties such as teaching how to spell alphabets, sing a song, play games, read some sentences, write, and answer quizzes. The material was delivered based on the LKS (student's worksheet) that was given by the headmaster of SD Muhammadiyah Jagalan as the internship supervisor. However, neither a syllabus nor lesson plans are provided in SD Muhammadiyah Jagalan. Therefore, the writer had an initiative to make an English syllabus subject that appropriate with the school curriculum. The syllabus is still related with learning activities because syllabus is a guidance for teacher in delivering the subject material in the class. Without syllabus teacher does not know material will be taught in the class. Cliff stated that " a disorganize, in complete, and hard to-read syllabus will make a negative impression in your study by showing them that you have not thought deeply about the organization of the course or what they will learn, and it may suggest that you are not very interested in giving students a highquality experience" (Cliff, 2015). This statement means that syllabus is very important in learning activities. The educators will not have sufficient directions in teaching in the class without syllabus. Based on this reasoning, the writer is interested in incorporating motor aspect in the syllabus of English, along with its implementation, in teaching English to second grade students of SD Muhammadiyah Jagalan.

\section{Methodology}

The underlying research of this article was carried out mainly through field study. The particular method was deemed most appropriate to use, since conducting study in the subject's context and location gives an authentic opportunity to learn the unexpected challenges and observe the objects of research in their real surroundings (Farell, 2016). Hence several techniques for collecting research data were applied, such as:

\section{Direct/Participatory Observation}

An observation to collect the data of research was carried out in SD Muhammadiyah Jagalan directly through teaching activities. Therefore, the characteristic of the observation is participatory as there was a direct involvement of researcher to the object of research.

\section{Interview}

There were several interviews conducted with the interviewees, namely the 
headmaster and teachers of SD Muhammadiyah Jagalan, about the syllabus of English applied and implemented in SD Muhamadiyah Jagalan. The main topic covered in the interviews were around the development of syllabus of English in SD Muhammadiyah Jagalan and its implementation in the teaching and learning activity. The interview data then were further analyzed, and conclusions were drawn.

\section{Library Research}

In addition to collecting data, there are also library research including reading several books, searching on the Internet about information related to the topic, and taking references from dictionary to find the meaning of words.

\section{Result and Discussion}

When the observation was conducted, there was no syllabus of English in SD Muhammadiyah Jagalan, especially in the second grade which were designated specifically as the sample for the syllabus development. An initiative was then made to formulate a syllabus subject of English that was developed in the class.

This syllabus is adjusted with the students' needs including grades, ages and characteristics. This case, the writer had observed in second grade of SD Muhammadiyah Jagalan. The writer designed the syllabus with fun learning implementation, including printing pictures, playing games, and singing a song-based on the student's characteristic development. According to Piaget (qtd. Perkembangan Peserta Didik) the development of cognitive aspects is characterized with (1) the students' ability to classify objects based on their characteristics, (2) ability to count numbers and solve simple problem. The age of elementary school students between 7 until 12 years, that are characterized with the motoric activity. Therefore, this very age is the right time for learning skills, that correlation with motoric development. Based on the book titled Perkembangan Peserta Didik, the motoric development can be divided in two categories. The first is fine motor, characterized by students' ability to write, draw, type in computer, sew, and make handicraft, among other examples. Second is hard motor that characterized by students' ability in self-defense, swimming, athletic, and walking, among other examples. The syllabus developed in the English class is then incorporated with these principles in order to make students' 
learning process to better suit their growing age.

\section{The Principles of Syllabus Development}

Syllabus is known as the main component for teachers in learning program which is ci a guidance for teacher to compose the material that will be given in the class, lesson plan in subjects, and many more. Basically, syllabus is composed by teachers in the school, which is commonly tailored from their own development of their subjects. When the composition of syllabus is finished by teacher, it can be implemented in class. According to Mulyasa (2007), teacher needs to pay attention about the principles of syllabus development, namely scientific, (2) relevant, (3) flexible, (4) continuous, (5) consistent, (6) adequate, (7) actual and contextual, (8) effective, and efficient.

\section{Scientific}

When a teacher makes a syllabus, which contain the materials and learning activities the syllabus must be; accurate, logical, and can be accounted scientifically.

\section{Relevant}

Relevant means that the scope of study, level of difficulties of the syllabus material presented by teacher should be adjusted with; the characteristics of students, intellectual and social cognitive. Besides, being relevant means there should be an adjustment between syllabus and actual circumstances - what the society needs in the real world-in both quality and quantity.

\section{Flexible}

The flexibility can be divided into two perspectives: first is the flexibility as educators and second is as curriculum implementation. The flexibility as educators is more emphasized to the students and alumnus. As for the flexibility as curriculum implementation, this perspective still has a relation with syllabus implementation. The teachers serve as syllabus implementers in the class. They should not depend solely on what they can make of, but instead they should develop their own ideas and improve their new ideas. It should be noted that educators should well understand the materials that will be given to students. The materials given is based on student's abilities, and their characteristic. Further, the students as learners can understand the material that educator have delivered based on their level of abilities. Flexibility for alumnus means that they have capabilities that are related to field work.

\section{Suitable}

Suitability means that learning program should have correlation between one topic 
to another topic in a lesson. The aim of this suitability is to form competence forming and the character of the students.

\section{Consistent}

In the development of syllabus, teacher should make the syllabus consistently. It means that among standard competence, basic competence, indicator, main material, learning experience, sources, and assessment system have correlation with student's competence forming.

\section{Adequate}

Adequate means that; indicator scope, standard material, learning experience, sources, and assessment system that have implemented reach the basic competence that have applied.

\section{Actual and Contextual}

Actual and contextual means that; indicator scope, standard material, learning experience, sources, and assessment system that have developed should pay attention to science progression and technology in the real world.

\section{Effective and Efficient}

When teachers want to develop the syllabus, they should pay attention to the level of competence forming in the learning process that have applied. The effective syllabus can be implemented in the real learning activity or in the field work.
Efficient in the syllabus has correlation with the effectiveness of timing, saving the use and funds without decreasing the result of basic competences applied. The implementation of efficiency, to know the efficiency the syllabus is by comparing among funds, out-put, and time that used in the learning activity. Therefore, each teacher should be able to develop the syllabus and planning the lesson program as efficient as possible, without decreasing the quality of achievement and competence forming.

\section{The Procedure of Syllabus Development}

In his book titled Kurikulum Tingkat Satuan Pendidikan, Mulyasa states that in the syllabus development, there are nine outlines for the procedure of syllabus development. The outlines are (1) filling the identity column, (2) analyzing the standard competence, (3) reviewing and deciding the students' basic competence, (4) identifying the standard material, (5) developing learning experience, (6) formulating the competence achievement indicator, (7) deciding the proper model of assessment, (8) deciding the proper time allocation, and (9) deciding the proper learning resources. Below are the steps that the writer implemented in developing 
the syllabus to use in the place of internship:

\section{Filling the Identity Column}

In the fill identity column consist of; school name, subjects, class and semester, and time allocation. Here is an example of the identity column:

Table 1 . The Identity Column

\begin{tabular}{|ll|}
\hline \multicolumn{2}{|l|}{ SILABUS } \\
\hline Nama Sekolah & $:$ MI Muhammadiyah Jagalan \\
\hline Mata Pelajaran & $:$ Bahasa Inggris \\
\hline Kelas \& Semester & $:$ II $/ 2$ \\
\hline Alokasi Waktu & $: 12 \times 35$ menit \\
\hline
\end{tabular}

(Source: KTSP book, p.203)

\section{Analyzing the Standard Competences}

When the teachers want to analyze the standard competences in a subject, they should pay attention to (1) the order of hierarchy in discipline concept and the level of difficulties in the material, (2) the correlation between standard competences and basic competences in a subject, and (3) the correlation between standard competences and basic competences among different subjects.

\section{Reviewing and Deciding Basic Competences}

The teachers should pay attention to the process of reviewing and deciding basic competences including the order of hierarchy in discipline concept and the level of difficulties in material that is not appropriate with the standard contents, the correlation between basic competences in the subjects, the correlation between basic competences and standard competence.

\section{Identifying the Standard Material}

Identifying standard material can be considered along with the level of students' physical, intellectual, emotional, social development of the students, the benefit for students, time allocation, the correlation between the students and surrounding needs and the material actualization.

\section{Developing Learning Experience}

In developing learning experience is arranged by teacher for giving learning experience. It contains of mental and physical process through active interaction between students and their teachers, material, surrounding, various methods in learning process, and learning resource approach.

\section{Formulating the Competence Achievement Indicator}

The indicators are elaborated from basic competences that are further characterized by the good response from students, the development of indicator that was based on the characteristics of students, the observability of the indicator 
and its wide use for a basic in assessment standard.

\section{Deciding the Kind of Assessment} (Assessment Standard)

The assessment standard conducted by the indicator; the teacher can assess the students from the exam. Besides, teacher can do observe the students' performance, their attitude, masterpiece from their product, and evaluation.

\section{Deciding the Time Allocation}

Deciding time allocation is based on total of effective week and time allocation for subject. The teacher should consider total of basic competence, level of difficulties in subject, and the level of importance subject itself. The things that should pay attention is Kalender Pendidikan or Education Calendar from the Department of Educational Affairs Jawa Tengah Province. In a Head of Education Affairs Jawa Tengah Province regulation about time of learning activities mention that "The effective learning activities in each educational level are varied. Elementary School is 30', Junior High School 40', and Senior High School 45'. The total of time in learning activities in each semester minimum is 18 weeks."

\section{Deciding the Learning Resources}

Learning resources is a reference and material that teacher usually used for learning activity in the class. The learning resources can be used; electronic media and printed media, sources, and many more. Deciding the learning resources is based on standard competence, main material, and learning activity.

\section{The Process of Syllabus Development}

The aim of this process is to make easy the teacher and headmaster in develop syllabus. The teacher should know that there are several terms about process of syllabus development, including; planning, implementing, and evaluating.

\section{Planning}

In this process planning is very important for teacher in developing the syllabus that they made. They should collect the information and reference for their material further, identifying the learning resources source is one of the important things that teacher needs. The teacher also can get by using technology, internet and computer as collect and increase information and reference.

\section{Implementing}

In implementing the syllabus, the teacher should formulate the competence and the purpose of learning activity, also decide the standard material that contains; basic competence, standard material, result of study, and indicator. Then, decide 
the strategy, method and learning purpose based that appropriate with learning model. After that, analyze the syllabus based on time allocation that is appropriate with curriculum, learning activity, result of study, curriculum management, and class assessment.

Further in implementing of the syllabus in the class, the writer adopted a syllabus that was applied (see in the appendix 2.1). The formula of syllabus that will be implemented by the writer about the competence and the standard material also refers too that syllabus. The writer is adopting that syllabus as a guidance and reference in developing syllabus subject in SD Muhammadiyah Jagalan. The writer also elaborates the contain inside, and renew that syllabus based on the characteristic, age, the students needed, and the level of study. Besides, in analyzing the syllabus the writer also refers to the regulation of Education Office Affairs Jawa Tengah, especially in time allocation.

In deciding the strategy and method in learning material, the writer used the various materials into learning activities in the class. The learning activities are singing together in the class, latching the shape of object, and guessing the meaning from the word. In the learning materials, an emphasis was not only put from the book that was provided from the headmaster of SD Muhammadiyah Jagalan, but also from another reference in form of literatures, such as books and internet articles.

\section{Evaluating}

The syllabus developed should undergo meticulous and regular evaluation, covering aspects namely: the validity of syllabus, the assessment criteria, and its actual performance implementation. Further, syllabus will get revision to improve the continuous quality improvement of syllabus.

\section{The Format of Syllabus}

The newly developed syllabus then contains several main goals, namely; standard competence, basic competences, indicators, standard materials, learning process and assessment criteria. The format of syllabus is described below:

Table 2. The Format of Syllabus

FORMAT SILABUS KTSP

Nama Sekolah :

Mata Pelajaran :

Kelas/Semester :

Alokasi Waktu

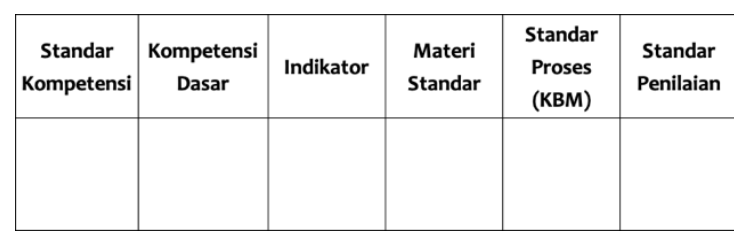

(Source: KTSP book, p.208) 
a) Standar Kompetensi or Competence Standard: the aim of learning process in general.

b) Kompetensi Standar or Basic Competence: an elaboration about what the standard competence explains.

c) Indikator or Indicator: the main material that will be delivered

d) Materi Standar or Standard Material: the material that will be taught by teacher.

e) Standar Proses or Process Standard: the activities between students and teacher in the class.

f) Standar Penilaian or Assessment Standard: the standard based on the process of assessing in the class, it can be speaking test, quizzes, writing test.

Several Aspects to Consider in a Syllabus Development

In preparation and development phase, the syllabus is designed by syllabus developers' team that should consider and pay attention with the principal of syllabus. There are several things that needs to pay attention in syllabus development includes; indicator, subject matter and learning activity.

\section{The Indicator}

The indicator refers to main material that used to know about competence achievement. The competence achievement includes; attitude, skills, and knowledge of students based on basic competence.

\section{The Learning Material}

The subject matter used to each basic to achieve the competence, based on standard competence and basic competence in each subject.

\section{A Syllabus Model Based on KTSP}

The syllabus can be modified by teacher, adjusted with the characteristics of students, the condition of the school and location, and the students' ability. However, teachers should pay attention with standard competence and basic competence that was applied. For details about model of syllabus based on KTSP, will be explained in an example of syllabus below. 


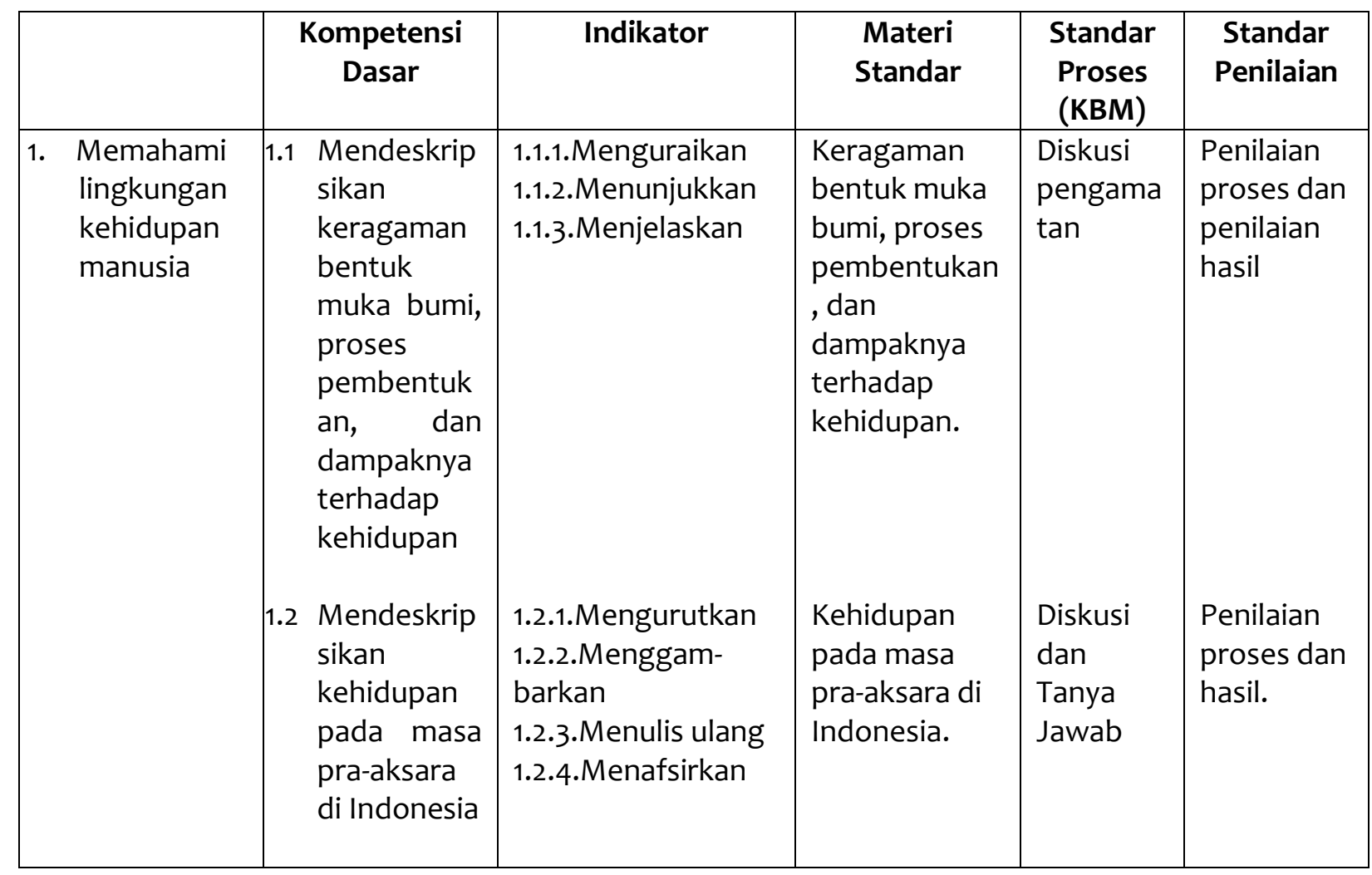

Table 3. The Format of Syllabus

\section{SILABUS}

Nama Sekolah : Sekolah Menengah

Pertama (SMP) /

Madrasah Tsanawiyah

(MTs)

Mata Pelajaran : Ilmu Pengetahuan Sosial

Kelas/Semester : VII / Semester 1

(Source: KTSP book, p.210) 


\section{The Provide Books}

Several concepts from books were taken as references to conduct the research process. The provide books including from Student Worksheet known as Lembar Kerja Siswa from SD Muhammadiyah Jagalan as reference in deciding the material in the syllabus, the printed books resources, and internet references book. Further, the material inside is appropriate to the condition of the students in SD Muhammadiyah Jagalan. The reason the writer chooses those resources because they are adjusted by the characteristic, age, and level of difficulties of the students. The aim makes the students interested in learning English. Further, the various materials inside, interested picture, the guidance to do assignment easy to understand by the students.

\section{Fokus LKS or Student Worksheet}

This book serves as a standard handout for teaching English in the second grade of SD Muhammadiyah Jagalan. The content material of this book for $2^{\text {nd }}$ are school activities, things in the library, uniform, and animals. The subject teacher always uses this book when she teaches in the class. In the fact, there is no syllabus that is applied in SD Muhammadiyah Jagalan. Therefore, the teacher uses this
Student Worksheet as guidance in learning English and the material that delivers also from the Student Worksheet. Then, the writer had an initiative to make syllabus for learning English that refer to the Student Worksheet. Actually, the writer is only using some materials in the Student Worksheet because some materials inside inappropriate with the level difficulties of the students. The writer renews and adopted some materials inside it, then rewrite into the simple context. Thus, the materials easy to understand by the students. Lembar Kerja Siswa or Student Worksheet known as guidance and make easy for student in learning activity. The content of it include the tasks and step of do the task. The aim of this Student Worksheet helps students in creativity development, as guidance for teacher and student in learning activity process, and this also helps variation in learning activity.

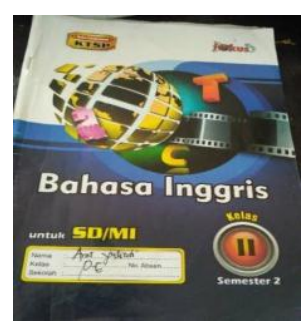

Picture 1. A Student Worksheet or Lembar Kerja Siswa Fokus (Source: Dian Ayu Septiani, April $7^{\text {th }}$, 2017) 


\section{A Printed Book Resources}

Printed book that the writer choose was Kamus Bergambar \& Game Seru Bilingual. This book was conducting the material that not provided in the school, this aim to decrease feel bored that student face in the class. Kamus Bergambar \& Game Seru Bilingual book contains; various games, interested picture, and lyrics song. Besides, to increase students' knowledge about the lesson that they have not received in LKS, it also to increase their vocabulary, and improve their skill in English lesson.

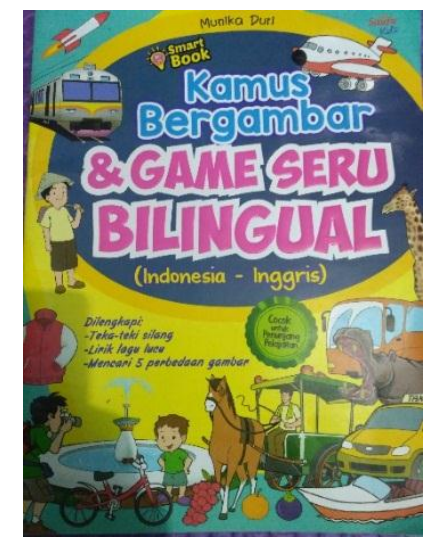

Picture 2. An English Printed Book (Source: Dian Ayu Septiani, February $26^{\text {th }}, 2017$ )

\section{An Internet References Books}

The material in internet reference book helped writer to take material that will deliver in the class. In these books there are some materials content, includes; family, my friends, colors and shape, myself, clothes, our school, food, seasons and festivals, and animals. The aim is to increase knowledge students. From the materials inside the writer can combine one material to another material. The most activity in this book is coloring pictures, so it made students enjoy and fun while learning English in the class.

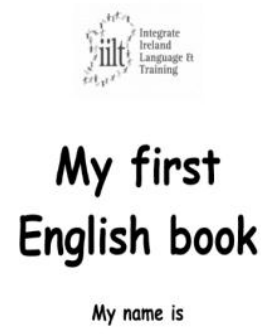

Picture 3. Internet references book (Accessed by Dian Ayu Septiani, September $3^{\text {rd }}$, 2016)

\section{The Implementation of an English Syllabus}

\section{Subject Development}

Syllabus is the most important for teachers when they want to deliver the material in the class. Without syllabus, the teachers do not know what material will deliver, and what activity in the syllabus. The writer made this syllabus by considering the grade, age, characteristic of students. Besides, the writer is also following the theme or material in Student Worksheet. The process of made this syllabus not only considering among the grade, age, and characteristics of students, but also the observation in the first meeting. The observation in the first meeting was helped the writer in designing the syllabus. Further, the writer decided 
that second grade class in an English syllabus subject development.

Second grade class contain 22 of students, the number of students most lot from the other classes. The reason why the writer chooses this class is that the amount of meeting in second grade class is more than the other classes. Besides the teacher always cooperative and gives the space for the writer do the observation. Thus, the writer has opportunity in learning English. In the first meeting until the second meeting the second class is very noisy the students running around in the class, talk each other with their friends, not interested in learning English and do not pay attention when the writer delivers the materials in the class. Therefore, the writer decides to design the fun learning activities for second grade school through the syllabus development. The writer provides, the various material from some books and reference to conduct in learning activities. The learning activities in the class are drawing the picture, singing together, and coloring the object.

In developing English syllabus subject, the writer adopts the material from the other syllabus as a basic in decide the material that will deliver. In this Paper, the writer will give one of example the result of material in implementing an
English syllabus subject in second grade class (see in the appendix 2.2). The material is Describing Animals this material aims to build the student's self-confidence through describe the physical appearance of animals. Further, the writer gave the song lyrics about the animals. It aims to make the students recognize and remember the names of animals in English. After that between students and teacher are singing together. Singing can make the students feel happy and enjoy. The impact of sing together is decreasing student talk each other, and shout-out in the class.

In the competency column, the writer mentioned about tell the color, food, parts of body, and life of the animals. This competency still related with the material before. Further, every day the writer asks students to bring pencil color in this material. The aim of it is, to reduce the students' boredom. The coloring activity will be done in last session, the writer gives a piece of paper to students. The instruction is, they should draw and color their favorite animal.

In the material about describing animals, the students will be able in describing the physical appearance of animals, reading word and spelling alphabet, and complete the missing word. The writer decided this competency into 
three activities based on language item or content. The first is listening and speaking, second is reading, and the last is writing.

The first is listening and speaking language item, in the competency mentioned that the students will be able to tell the color, parts of body, live. Further, in the language item column, the writer uses simple present tense in describe the animals. In the learning activities and resources column, the activities are the writer pointing the students one by one randomly, the question about their favorite animals. Further the writer writes them down the white board in only 5-8 example of animals. Furthermore, the writer mentions one of animal ask about the physical appearance by using simple present context. In the sing a song part, the writer asks all of students to stand up and the writer deliver the lyric song in a piece of paper. The writer gives the example and the students follow it. The song aims to reduce their boredom and recognize the students about vocabulary.

The second is reading language item, the activities the writer gives some vocabularies about the animals. Then, the writer read word by word after that students follow that word. The writer points 5 students randomly to read the word. Further, the writer gives example how to spell alphabetic, for example CAT= C-A-T. The writer spell first, and after that the student follow it.

The third is writing language item, the activities of writing are asking the students to write down the vocabularies in their own book. The assignment of the writing is completing the missing words.

From the example of activities about Describing Animals materials, proven that the students enjoy in learning English. The noises reduced, students always pay attention in the class, students also focus on material that are delivered.

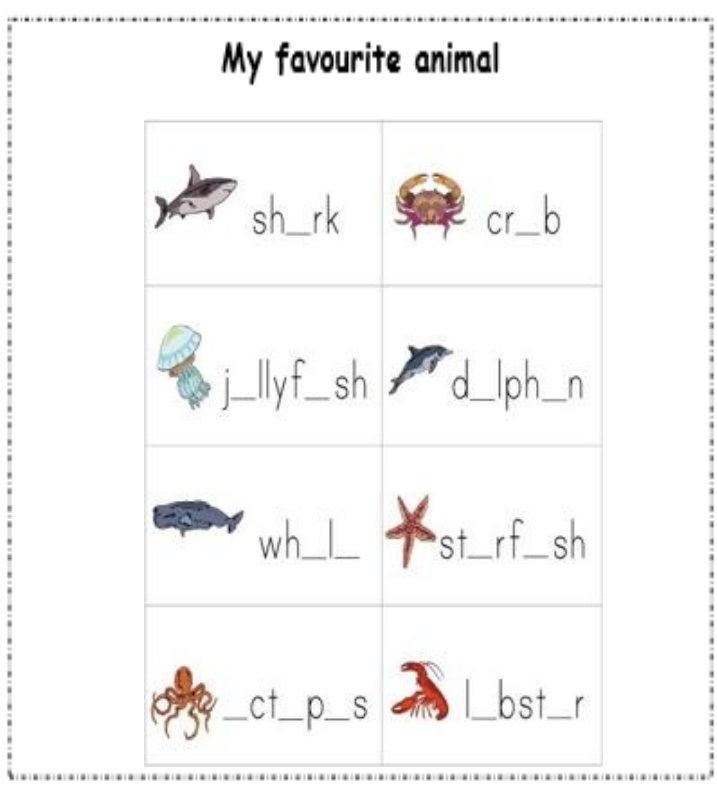

Picture 4. An English Printed Book (Source: Dian Ayu Septiani, February 26 ${ }^{\text {th }}, 2017$ ) 
Unit 6:

\section{Describing Animal}

\section{Unit Outcomes:}

Students will be able to:

- Describe the physical appearance of animals

- Read alphabet and spell

- Complete word

Writing

Students draw and coloring their favorite animal after that describe it.

\begin{tabular}{lll}
\multicolumn{2}{l}{ Vocabulary } & Lyric \\
Bird & : Burung & Kucing cat \\
Buffalo & : Kerbau & Tikus Mouse \\
Cat & : Kucing & Bebek Duck \\
Butterfly & : Kupu-kupu & Ikan Fish \\
Chicken & : Ayam & Gajah Elephant \\
Chipmunk : Tupai & \\
Cow & : Sapi & \\
Dog & : Anjing & \\
Fish & : Ikan & \\
Goat & : Kambing & \\
Hamster & : Hamster & \\
Horse & : Kuda & \\
Lion & : Singa & \\
Monkey & : Monyet & \\
Pigeon & : Merpati \\
Rabbit & : Kelinci \\
Sheep & : Domba \\
Turtle & : Kura-Kura
\end{tabular}

\section{Conclusion}

There are five ways to develop an English syllabus subject based on KTSP namely: implementing the principal of syllabus development, procedure of syllabus development, process of syllabus development, format of syllabus. On the other hand, the things that need to pay attention, are provide books containing guidance for developing KTSP-based syllabus, and the implementation of an English syllabus were also conducted in develop an English syllabus subject.

Second, the provide books was used as conducted an English syllabus subject in SD Muhammadiyah Jagalan. There are three provide books that used as conducting an English syllabus subject. The Lembar Kerja Siswa or Students Worksheet was provided by the headmaster of SD Muhammadiyah Jagalan. It serves as a main guidance in SD Muhammadiyah Jagalan for teacher when delivers the material in the class. The printed book was aimed to fulfill the materials that not provide in Student Worksheet. An internet reference books aims to combining the materials among Students Worksheet and the printed book.

Third, the result of the students after an English syllabus subject was implemented in SD Muhammadiyah Jagalan. Before an English syllabus subject applied, most of the students not pay attention in the class. The students feel bored with the material. The impact of it is 
the students lack their self-confidence, talk each other and running around in the class. Further, after an English syllabus subject was implemented, the students always pay attention in each material. They are feeling happy and enjoy in learning English. Furthermore, the most of them are always participating when the teacher gives an assignment in the class, because their selfconfidence was built.

\section{References}

Badan Standar Nasional Pendidikan, Educational Office Affairs. (2006). Panduan Penyusunan Kurikulum Tingkat Satuan Pendidikan. Print.

Bearre, Keneth. (2017). Elementary Level Syllabus for Beginner Level CoursePart I Lesson 1-9, vol. 1. [E-Reader version] Retrieved from http://www.thoughtco.com/eleme ntary-level-syllabus-1212162.

Accessed 1 June 2017

Cliff, E. (2016). Syllabus. Tonic for The Boring Syllabus. Retrieved from http://www.facultyfocus. com/articles/effective-classroommanagement/tonic-for-the-boringsyllabus/.

Accessed 1 June 2017

Duri, Munika. (2015). Smart Book:Grammar and Conversation Book Smart: Kamus Bergambar \& Game Seru Bilingual. Yogyakarta: Saufa Kids.
Farrel, Susan. (2016). Research Methods. Retrieved from https://www.nngroup.com/articles/ field-studies/. Accessed 1 June 2017

Febriana, Pramesintha. (2016). Personal Interview.

Jonathan, Sarwono. (2006). Metode Penelitian Kualitatif Kuantitatif. Yogyakarta: Graha Ilmu.

Magelang. Central Java. Education Office Affairs. Kalender Pendidikan. By Pemerintah Provinsi Jawa Tengah: Ministry of National Education, Nov. 2016. Web. Accessed 2 June 2007.

Mulyasa, E. (2007). Kurikulum Tingkat Satuan Pendidikan. Bandung: PT Remaja Rosdakarya.

Nurhuda, Muh. Personal Interview. April $25^{\text {th }}, 2016$.

Pradeska, Yuviter. Perangkat Pembelajaran RPP, Silabus, Prota, Promes, SD KTSP, 1 June 2016. www.guru-id.com/2016/07/rppsilabus-prota-promes-SDKTSP.html. Accessed 1 June 2017.

Purnomo, Hadi. (2010). Kamus Ideal: Grammar dan Conversation. Surabaya: Anugrah.

Rooijakers. (1991). Mengajar Dengan Sukses: Petunjuk untuk Merencanakan dan Menyampaikan Pengajaran. Jakarta: Pershindo.

Salim, Peter. (1987). The Contemporary English Indonesian Dictionary. Jakarta: Modern English Press. Web. Accessed 1 June 2017

Trianto. Model Pembelajaran Terpadu Kurikulum Tingkat Satuan Pendidikan. Jakarta. Bumi Aksara.

Yuliati, Anis. Personal Interview. April $19^{\text {th }}$ 2016. 